\title{
The Relationship Between Organizational Culture and Employees' Satisfaction Shown on the Example of Tourism Businesses in Montenegro
}

\author{
Olivera Simovic \\ Faculty of Tourism and Hospitality, University of Montenegro, Montenegro \\ Djurdjica Perovic \\ Faculty of Tourism and Hospitality, University of Montenegro, Montenegro \\ Milica Raicevic \\ Faculty of Economics and Business, Mediterranean University Podgorica, \\ Montenegro
}

\section{Abstract}

Organizational culture, as an area of management is a complex system of mutual values that creates an organization's identity and makes it different from the competition. The aim of this paper is to create an adequate approach for improving competitive advantages and better performance of Montenegro's tourism businesses through improving business environment as one of the competitiveness factors. Through this work, the relationship and influence between the type of organisational culture and employees' satisfaction is being determined and analysed through different dimensions of the work they are doing. For the needs of this work a quantitative explorative research has been done, using the method of questionnaire. In the questionnaire, the Organizational Culture Assessment Instrument (OCAI) and the Test for measuring employees' satisfaction have been used. The obtained results show us the type of organizational culture that is characteristic for tourism businesses in Montenegro, as well as the influence it has on the level of employees' satisfaction, through different dimensions. Business environment that increases the level of job satisfaction of employees contributes to loyalty and achieving better results in tourism businesses.

Keywords: organizational culture, management, employees' satisfaction, tourism businesses

JEL classification: L29

\section{Introduction}

Job satisfaction is an important factor that gives company management a signal on how to shape a working environment that will keep experienced, loyal and most hardworking workers. Job satisfaction is also the most commonly discussed phenomenon in the field of human resources management, because knowledge of the organizational condition of job satisfaction has an important practical value for the employer who sees in it an asset to maintain the most valuable employees. Willingness of employees to change work depends on the factors like: connection to co-workers and activities during work, similarities and fitting between work and other life aspects, an ease of breaking these links, especially if change of work implies changing the 
place of residence. If personal values of the employees, their goals are connected to their career, plans for future adaptability to organizations' corporative culture and their personal requirements for work, employees' intention to leave is reduced and change of work and at the same time positively influences job satisfaction (Wnuk, 2017).

Job satisfaction and organizational culture are in an interconnection, so many researchers of organizational culture observe it as a factor which affects the degree of job satisfaction (Macintosh \& Doherty, 2010; Silverthorne, 2004; Lund, 2003; Lok \& Crawford, 1999; Johnson \& McIntye, 1998; Nystrom, 1993; Odom et al., 1990). Thus Lund (2003) researching and analysing the influence of certain types of organizational cultures on work satisfaction. Earlier researches (Lok \& Crawford, 1999; Johnson \& Mclntye, 1998; Maclntosh \& Doherty, 2010), have proved interconnections and basic mechanisms on the relation of organizational cultures and employees' work satisfaction.

Although many heterogeneous views on the definition of the term organizational culture can be found in scientific literature; most authors from the field of management define organizational culture as a complex system of common values which the members of an organization lead on their actions and activities. (O'Reilly III et al., 1991) Values like unity, creativity, performances and efficiency seem like the base of an organization's culture, which creates the organization's identity and separates from the competition (Denison, 1984; Sørensen, 2002).

Individual's job satisfaction in itself sublimates, cognitive and evolation components, which stems a complex view of dimensions of the work that the person is doing on a daily basis (Luthans, 2005; Kinicki et al., 2002). To the degree of the individual's satisfaction of the work they perform influences not only specific characteristics of the work they do, but also the importance of these characteristics from the individual's aspect. Job satisfaction is the result of individual experience. The meaning of the concept of job satisfaction comes from a positive influence of work satisfaction on the increase in employee productivity (Judge et al., 2001). Luthans (2005) has defined factors which affect the job satisfaction with aspects of organizational and individual levels. The organizational level factors include: job characteristics, wage system, work conditions, style of managing an organizational structure and colleges. Individual-level factors include the following relationships: balance between personal interest and work; work experience and age; hierarchical positions and collective life satisfaction.

Organizational culture is an organizational factor which has influence on job satisfaction. Organizational culture is an important factor which determines internal environment of the organization in which members of the organization perform their work and achieve wanted results (Schein, 2004).

The most representative definition in literature is considered Edgar's Schein according to which organizational culture presents represents a form of common basic assumptions which a group has learned by solving a problem external adaptation and internal integrations and which function good enough to be considered valid and to be transferred to new members of the organization as a correct way of perception, thoughts and feelings in relation to those problems (Schein, 2004).

Classifications of organizational culture have appeared either as a result of generalizing the author's experience, like in the case of the Handy classification (Handy, 1979), or as a result of empirical research, like the case of the Cameron and Quinn classification (Cameron \& Quinn, 1999). Mentioned authors classify organizational culture into four basic categories. Charles Handy (Handy, 1979) 
classifies organizational culture as: cultural power, cultural role, culture of the task and culture of the personality. According to the classifications of Cameron and Quinn (Cameron \& Quinn, 1999) what stands out is: culture of clans, culture of hierarchy, culture of adhocracy and culture of the market. Types of cultural classification which we will is the one given by Kim Cameron and Robert Quinn (Cameron \& Quinn, 1999) from the university of Michigan (USA). According to classification of Cameron and Quinn there exist 4 basic types of culture: culture of clans, culture of hierarchy, culture of adhocracy and culture of the market. Culture of clan gives priority to flexibility and autonomy in relation to stability and control. This implies strong interpersonal relationships and mutual support. Culture of hierarchy characterizes strict formality and structural surrounding, focused on achieving as much efficiency Culture of hierarchy refers to flexible, adaptable and non-formal shape of organization which characterizes entrepreneurial spirit and innovation in solving problems. Culture of the market characterizes external orientation in combination with stability and control (Janićijević, 2013).

Robbins (Robbins, 1993) and Hutcheson (Hutcheson, 1996) suggest that, since the dimensions of job satisfaction are components to organizational culture, job satisfaction can be served to evaluate the organizational culture. They describe work satisfaction as a remainder between the outcome that the employee expects from the job and the outcome which the receive in reality. Evaluation of different work aspects from the employees is very subjective and individuals show different levels of satisfaction from the same factors. Janićijević, Nikčević and Vasić (Janićijević, Nikčević and Vasić, 2018) refer that organizational cultures should be included in organizational factors which effect job satisfaction, because values and norms which are formed in a certain organizational culture become a part of organizational context in which work is being done, a Given that these values influence the quality of relationships and processes inside the organization, It stems that they influence on a degree that organizational cultures create a favourable or unfavourable business environment.

Job satisfaction is based on the perception of the individual about how much does work give to the individual that is valuable (Locke, 1969). From this perspective we conclude that an individual compares his expectations and the perception in the view of a job's specific characteristics and their satisfaction characteristics. The smaller the gap is between the significance of job characteristics and satisfaction of job characteristics the work satisfaction is larger. The key value here is to identify job characteristics which employees' value especially important for their work ethics. Some of the previous studies (Kinicki et al., 2002) have shown that employees especially consider the wage, associates, supervision, possibility of a promotion as well as the work itself, in assessing the work itself and satisfaction itself. In a research conducted for needs of this work it is taken into consideration the next dimensions of work: height and regularity of wages, benefits, teamwork, independence during work, job security, possibility of a promotion and professional development, relationships with colleagues and supervisors, challenging work, good physical working conditions, care of employees for employees, as well as how much the work we do is important not only for the company but overall the society.

\section{Methodology}

The goal of work is to determine and analyses connections and influence between types of organization culture and employee satisfaction throughout different dimensions of work they do, to create an adequate approach to improve competitive 
advantages and better work performances of Montenegrin touristic enterprises, through improving work ambient, as one of the competitive factors.

For work requirements quantitative exploratory research was conducted, using method of survey. The survey used instruments for determining organization culture (OCAI) and a Test for measuring employee satisfaction in different dimensions of work. The results that we come to show the type of organization culture which characterizes touristic enterprises in Montenegro and the influence on the degree of employee satisfaction which work in given business environment, through different dimensions. The data was processed in SPSS I except descriptive statistic which was use in correlation and hi-square for analysis of connection and differences. Work ambient which increases employee satisfaction while doing business tasks, contributes loyalty and better business result in touristic enterprises.

\section{Results}

In this study we analysed 74 companies and in total 1312 employees, which mean in average 17,73 ( $\min =1$, $\max =$ ) employees from each company.

Figure 1 shows structure of companies (categories: hotel, travel agency, restaurant), while Table 1 shows characterization of companies regarding organization culture.

Figure 1

Structure of Companies

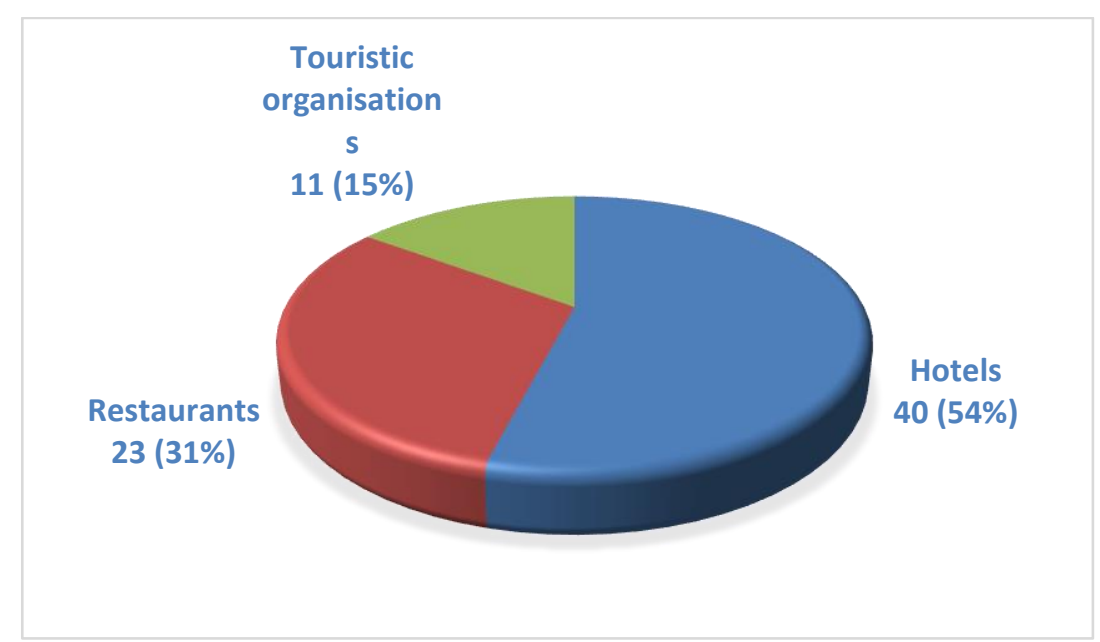

Source: Authors' illustration

Table 1

Characterization of Companies Regarding Organization Culture

\begin{tabular}{lcccccc}
\hline \multicolumn{1}{c}{$\begin{array}{c}\text { Type of } \\
\text { organizatio } \\
\text { n culture }\end{array}$} & $\begin{array}{c}\text { Dominant } \\
\text { organization } \\
\text { characteristi }\end{array}$ & $\begin{array}{c}\text { Leadership } \\
\text { in } \\
\text { organizatio }\end{array}$ & $\begin{array}{c}\text { Human } \\
\text { resource } \\
\text { manageme }\end{array}$ & $\begin{array}{c}\text { Unity of } \\
\text { organizatio }\end{array}$ & $\begin{array}{c}\text { Strategical } \\
\text { focus }\end{array}$ & $\begin{array}{c}\text { Criteria for } \\
\text { success }\end{array}$ \\
Clan & $55(74,32 \%)$ & $54(72,97 \%)$ & $65(87,84 \%)$ & $52(70,27 \%)$ & $52(70,27 \%)$ & $51(68,92 \%)$ \\
Adherence & $8(10,81 \%)$ & $8(10,81 \%)$ & $2(2,70 \%)$ & $10(13,51 \%)$ & $11(14,86 \%)$ & $9(12,16 \%)$ \\
Market & $7(9,46 \%)$ & $1(1,35 \%)$ & $3(4,05 \%)$ & $3(4,05 \%)$ & $4(5,40 \%)$ & $2(2,70 \%)$ \\
Hierarchy & $4(5,40 \%)$ & $11(14,86 \%)$ & $4(5,40 \%)$ & $9(12,16 \%)$ & $7(9,46 \%)$ & $12(16,22 \%)$ \\
\hline
\end{tabular}

Source: Authors' work 
It can be seen that majority of companies have organization culture of Clan, which implies good interpersonal relations, in which friendliness, mutual support and teamwork prevails. At the same time the leader of the organization which has the role of a mentor and leader is respected.

Figure 2

Overall Satisfaction at Companies

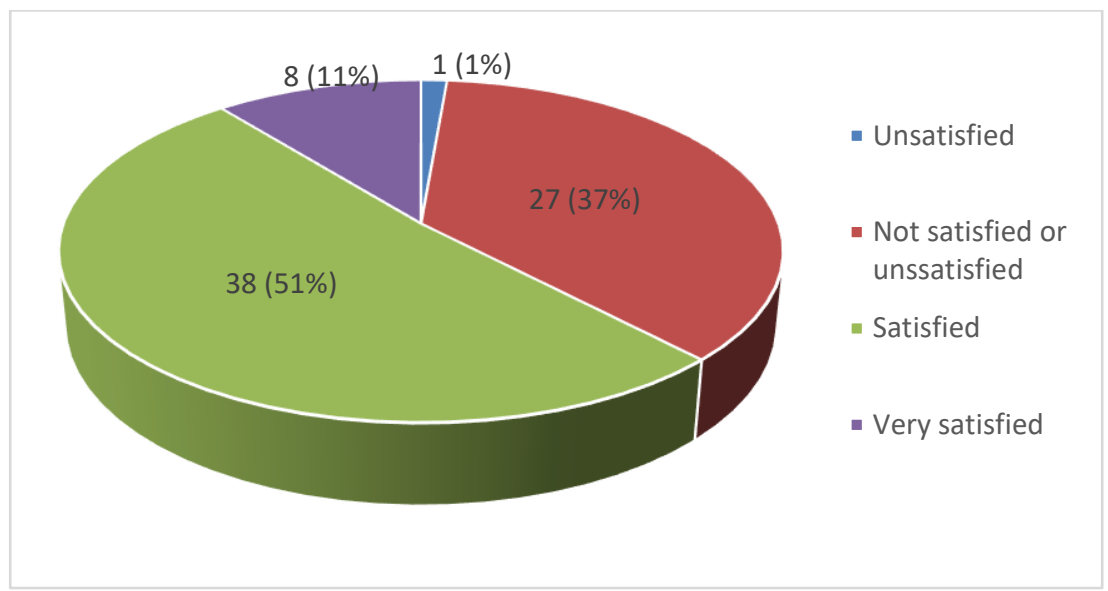

Source: Authors' illustration

Figure 2 illustrates overall satisfaction in companies, where majority of employees are Satisfied (51\%), while $11 \%$ are very satisfied. It is important to highlight the number of neither satisfied nor unsatisfied employees (37\%), which means that almost each third employee belongs to this category.

Furthermore, the Tables 2-4 present correlation coefficient between 15 different dimensions of satisfaction, with bolded values of medium intensity of correlation (range values: $0,5-0,8$ ). It can be seen (Table 3) that dimensions of Teamwork, Independence in business, Security of employment, Regularity of pay, Possibility of professional development, and Possibility of promotion at work are significantly correlated between each other. Also, dimensions (Table 2, Table 4) of Absence of conflict in the company, Employee care for employees, Good physical working conditions, and Good relations with the immediate manager, are significantly correlated with almost each other dimension. 


\section{Table 2}

Analyses of Correlation in the Level of Satisfaction with Different Dimensions (Part I)

\begin{tabular}{|c|c|c|c|c|c|c|c|}
\hline & $\begin{array}{l}\text { Absence } \\
\text { of } \\
\text { conflict } \\
\text { in the } \\
\text { compan } \\
y\end{array}$ & $\begin{array}{l}\text { Employee } \\
\text { care for } \\
\text { employee } \\
s\end{array}$ & $\begin{array}{c}\text { A } \\
\text { challengin } \\
\text { g job }\end{array}$ & $\begin{array}{c}\text { Good } \\
\text { physical } \\
\text { working } \\
\text { condition } \\
\text { s }\end{array}$ & $\begin{array}{l}\text { Good } \\
\text { relations } \\
\text { with the } \\
\text { immediat } \\
\text { e } \\
\text { manager }\end{array}$ & $\begin{array}{l}\text { Benefits: } \\
\text { recovery, } \\
\text { transportation } \\
\text {, phone }\end{array}$ & $\begin{array}{l}\text { A job } \\
\text { important } \\
\text { for the } \\
\text { compan } \\
y \text { and } \\
\text { society }\end{array}$ \\
\hline Salary & $\begin{array}{c}0,410 \\
(p<0,000)\end{array}$ & $\begin{array}{c}0,450 \\
(p<0,000)\end{array}$ & $\begin{array}{c}0,301 \\
(p<0,000)\end{array}$ & $\begin{array}{c}0,434 \\
(p<0,000)\end{array}$ & $\begin{array}{c}0,432 \\
(p<0,000)\end{array}$ & $\begin{array}{c}0,418 \\
(p<0,000)\end{array}$ & $\begin{array}{c}0,465 \\
(p<0,000)\end{array}$ \\
\hline Teamwork & $\begin{array}{c}0,580 \\
(p<0,000)\end{array}$ & $\begin{array}{c}0,548 \\
(p<0,000)\end{array}$ & $\begin{array}{c}0,391 \\
(p<0,000)\end{array}$ & $\begin{array}{c}0,535 \\
(p<0,000)\end{array}$ & $\begin{array}{c}0,553 \\
(p<0,000)\end{array}$ & $\begin{array}{c}0,305 \\
(p<0,000)\end{array}$ & $\begin{array}{c}0,435 \\
(p<0,000)\end{array}$ \\
\hline $\begin{array}{l}\text { Independenc } \\
\text { e in business }\end{array}$ & $\begin{array}{c}0,556 \\
(p<0,000)\end{array}$ & $\begin{array}{c}0,530 \\
(p<0,000)\end{array}$ & $\begin{array}{c}0,411 \\
(p<0,000)\end{array}$ & $\begin{array}{c}0,544 \\
(p<0,000)\end{array}$ & $\begin{array}{c}0,536 \\
(p<0,000)\end{array}$ & $\begin{array}{c}0,323 \\
(p<0,000)\end{array}$ & $\begin{array}{c}0,443 \\
(p<0,000)\end{array}$ \\
\hline $\begin{array}{l}\text { Security of } \\
\text { employment }\end{array}$ & $\begin{array}{c}0,491 \\
(p<0,000)\end{array}$ & $\begin{array}{c}0,547 \\
(p<0,000)\end{array}$ & $\begin{array}{c}0,414 \\
(p<0,000)\end{array}$ & $\begin{array}{c}0,554 \\
(p<0,000)\end{array}$ & $\begin{array}{c}0,570 \\
(p<0,000)\end{array}$ & $\begin{array}{c}0,409 \\
(p<0,000)\end{array}$ & $\begin{array}{c}0,452 \\
(p<0,000)\end{array}$ \\
\hline $\begin{array}{l}\text { Regularity of } \\
\text { pay }\end{array}$ & $\begin{array}{c}0,506 \\
(p<0,000)\end{array}$ & $\begin{array}{c}0,516 \\
(p<0,000)\end{array}$ & $\begin{array}{c}0,392 \\
(p<0,000)\end{array}$ & $\begin{array}{c}0,564 \\
(p<0,000)\end{array}$ & $\begin{array}{c}0,601 \\
(p<0,000)\end{array}$ & $\begin{array}{c}0,361 \\
(p<0,000)\end{array}$ & $\begin{array}{c}0,451 \\
(p<0,000)\end{array}$ \\
\hline $\begin{array}{l}\text { Possibility of } \\
\text { professional } \\
\text { development }\end{array}$ & $\begin{array}{c}0,479 \\
(p<0,000)\end{array}$ & $\begin{array}{c}0,538 \\
(p<0,000)\end{array}$ & $\begin{array}{c}0,486 \\
(p<0,000)\end{array}$ & $\begin{array}{c}0,580 \\
(p<0,000)\end{array}$ & $\begin{array}{c}0,579 \\
(p<0,000)\end{array}$ & $\begin{array}{c}0,480 \\
(p<0,000)\end{array}$ & $\begin{array}{c}0,519 \\
(p<0,000)\end{array}$ \\
\hline $\begin{array}{l}\text { Possibility of } \\
\text { promotion at } \\
\text { work }\end{array}$ & $\begin{array}{c}0,524 \\
(p<0,000)\end{array}$ & $\begin{array}{c}0,525 \\
(p<0,000)\end{array}$ & $\begin{array}{c}0,444 \\
(p<0,000)\end{array}$ & $\begin{array}{c}0,560 \\
(p<0,000)\end{array}$ & $\begin{array}{c}0,525 \\
(p<0,000)\end{array}$ & $\begin{array}{c}0,447 \\
(p<0,000)\end{array}$ & $\begin{array}{c}0,499 \\
(p<0,000)\end{array}$ \\
\hline $\begin{array}{c}\text { Good } \\
\text { relationships } \\
\text { with } \\
\text { colleagues }\end{array}$ & $\begin{array}{c}0,722 \\
(p<0,000)\end{array}$ & $\begin{array}{c}0,549 \\
(p<0,000)\end{array}$ & $\begin{array}{c}0,377 \\
(p<0,000)\end{array}$ & $\begin{array}{c}0,524 \\
(p<0,000)\end{array}$ & $\begin{array}{c}0,541 \\
(p<0,000)\end{array}$ & $\begin{array}{c}0,278 \\
(p<0,000)\end{array}$ & $\begin{array}{c}0,442 \\
(p<0,000)\end{array}$ \\
\hline
\end{tabular}

Source: Authors' work

Table 3

Analyses of Correlation in the Level of Satisfaction with Different Dimensions (Part II)

\begin{tabular}{|c|c|c|c|c|c|c|c|}
\hline & $\begin{array}{c}\text { Teamwor } \\
\mathbf{k}\end{array}$ & $\begin{array}{l}\text { Independenc } \\
\text { e in business }\end{array}$ & $\begin{array}{c}\text { Security of } \\
\text { employme } \\
\text { nt }\end{array}$ & $\begin{array}{l}\text { Regularit } \\
\text { y of pay }\end{array}$ & $\begin{array}{c}\text { Possibility of } \\
\text { professional } \\
\text { developme } \\
\text { nt }\end{array}$ & $\begin{array}{l}\text { Possibility } \\
\text { of } \\
\text { promotio } \\
\mathrm{n} \text { at work }\end{array}$ & $\begin{array}{l}\text { Good } \\
\text { relationship } \\
s \text { with } \\
\text { colleagues }\end{array}$ \\
\hline Salary & $\begin{array}{c}0,604 \\
(p<0,000)\end{array}$ & $\begin{array}{c}0,535 \\
(p<0,000)\end{array}$ & $\begin{array}{c}0,501 \\
(p<0,000)\end{array}$ & $\begin{array}{c}0,395 \\
(p<0,000 \\
1\end{array}$ & $\begin{array}{c}0,439 \\
(p<0,000)\end{array}$ & $\begin{array}{c}0,459 \\
(p<0,000)\end{array}$ & $\begin{array}{c}0,373 \\
(p<0,000)\end{array}$ \\
\hline Teamwork & - & $\begin{array}{c}0,723 \\
(p<0,000)\end{array}$ & $\begin{array}{c}0,606 \\
(p<0,000)\end{array}$ & $\begin{array}{c}0,554 \\
(p<0,000\end{array}$ & $\begin{array}{c}0,503 \\
(p<0,000)\end{array}$ & $\begin{array}{c}0,525 \\
(p<0,000)\end{array}$ & $\begin{array}{c}0,629 \\
(p<0,000)\end{array}$ \\
\hline $\begin{array}{l}\text { Independenc } \\
\text { e in business }\end{array}$ & - & - & $\begin{array}{c}0,653 \\
(p<0,000)\end{array}$ & $\begin{array}{c}0,594 \\
(p<0,000 \\
)\end{array}$ & $\begin{array}{c}0,501 \\
(p<0,000)\end{array}$ & $\begin{array}{c}0,502 \\
(p<0,000)\end{array}$ & $\begin{array}{c}0,558 \\
(p<0,000)\end{array}$ \\
\hline $\begin{array}{l}\text { Security of } \\
\text { employment }\end{array}$ & - & - & - & $\begin{array}{c}0,692 \\
(p<0,000 \\
)\end{array}$ & $\begin{array}{c}0,609 \\
(p<0,000)\end{array}$ & $\begin{array}{c}0,525 \\
(p<0,000)\end{array}$ & $\begin{array}{c}0,498 \\
(p<0,000)\end{array}$ \\
\hline $\begin{array}{l}\text { Regularity of } \\
\text { pay }\end{array}$ & - & - & - & - & $\begin{array}{c}0,688 \\
(p<0,000)\end{array}$ & $\begin{array}{c}0,532 \\
(p<0,000)\end{array}$ & $\begin{array}{c}0,543 \\
(p<0,000)\end{array}$ \\
\hline $\begin{array}{l}\text { Possibility of } \\
\text { professional } \\
\text { development }\end{array}$ & - & - & - & - & - & $\begin{array}{c}0,769 \\
(p<0,000)\end{array}$ & $\begin{array}{c}0,513 \\
(p<0,000)\end{array}$ \\
\hline $\begin{array}{l}\text { Possibility of } \\
\text { promotion at } \\
\text { work }\end{array}$ & - & - & - & - & - & - & $\begin{array}{c}0,620 \\
(p<0,000)\end{array}$ \\
\hline
\end{tabular}

Source: Authors' work 
Table 4

Analyses of Correlation in the Level of Satisfaction with Different Dimensions (Part III)

\begin{tabular}{|c|c|c|c|c|c|c|}
\hline & $\begin{array}{l}\text { Employee } \\
\text { care for } \\
\text { employees }\end{array}$ & $\begin{array}{l}\text { A challenging } \\
\text { job }\end{array}$ & $\begin{array}{l}\text { Good } \\
\text { physical } \\
\text { working } \\
\text { conditions }\end{array}$ & $\begin{array}{c}\text { Good } \\
\text { relations with } \\
\text { the } \\
\text { immediate } \\
\text { manager }\end{array}$ & $\begin{array}{l}\text { Benefits: } \\
\text { recovery, } \\
\text { transportation, } \\
\text { phone }\end{array}$ & $\begin{array}{l}\text { A job } \\
\text { important for } \\
\text { the company } \\
\text { and society }\end{array}$ \\
\hline $\begin{array}{l}\text { Absence of } \\
\text { conflict in the } \\
\text { company }\end{array}$ & $\begin{array}{c}0,699 \\
(p<0,000)\end{array}$ & $\begin{array}{c}0,419 \\
(p<0,000)\end{array}$ & $\begin{array}{c}0,537 \\
(p<0,000)\end{array}$ & $\begin{array}{c}0,541 \\
(p<0,000)\end{array}$ & $\begin{array}{c}0,326 \\
(p<0,000)\end{array}$ & $\begin{array}{c}0,416 \\
(p<0,000)\end{array}$ \\
\hline $\begin{array}{l}\text { Employee } \\
\text { care for } \\
\text { employees }\end{array}$ & - & $\begin{array}{c}0,562 \\
(p<0,000)\end{array}$ & $\begin{array}{c}0,600 \\
(p<0,000)\end{array}$ & $\begin{array}{c}0,527 \\
(p<0,000)\end{array}$ & $\begin{array}{c}0,395 \\
(p<0,000)\end{array}$ & $\begin{array}{c}0.450 \\
(p<0,000)\end{array}$ \\
\hline $\begin{array}{l}\text { A challenging } \\
\text { job }\end{array}$ & - & - & $\begin{array}{c}0,613 \\
(p<0,000)\end{array}$ & $\begin{array}{c}0,446 \\
(p<0,000)\end{array}$ & $\begin{array}{c}0,463 \\
(p<0,000)\end{array}$ & $\begin{array}{c}0,443 \\
(p<0,000)\end{array}$ \\
\hline $\begin{array}{l}\text { Good physical } \\
\text { working } \\
\text { conditions }\end{array}$ & - & - & - & $\begin{array}{c}0,666 \\
(p<0,000)\end{array}$ & $\begin{array}{c}0,455 \\
(p<0,000)\end{array}$ & $\begin{array}{c}0,494 \\
(p<0,000)\end{array}$ \\
\hline $\begin{array}{l}\text { Good relations } \\
\text { with the } \\
\text { immediate } \\
\text { manager }\end{array}$ & - & - & - & - & $\begin{array}{c}0,508 \\
(p<0,000)\end{array}$ & $\begin{array}{c}0,552 \\
(p<0,000)\end{array}$ \\
\hline $\begin{array}{l}\text { Benefits: } \\
\text { recovery, } \\
\text { transportation, } \\
\text { phone }\end{array}$ & - & - & - & - & - & $\begin{array}{c}0,619 \\
(p<0,000)\end{array}$ \\
\hline
\end{tabular}

Source: Authors' work

Table 5

Analyses of Dependencies between Different Organization Structure and Overall Level of Satisfaction in the Company

\begin{tabular}{|c|c|c|c|c|c|}
\hline \multirow{2}{*}{$\begin{array}{l}\text { Dimensions of } \\
\text { organization } \\
\text { structure }\end{array}$} & \multicolumn{5}{|c|}{ Overall job satisfaction } \\
\hline & Unsatisfied & $\begin{array}{l}\text { Neither satisfied } \\
\text { nor satisfied }\end{array}$ & Satisfied & Very satisfied & TOTAL \\
\hline \multicolumn{6}{|c|}{ Dominant organization characteristic } \\
\hline Clan & $0(0,00 \%)$ & $22(40,00 \%)$ & $28(50,91 \%)$ & $5(9,09 \%)$ & $55(74,32 \%)$ \\
\hline Adherence & $1(12,50 \%)$ & $4(50,00 \%)$ & $2(25,00 \%)$ & $1(12,50 \%)$ & $8(10,81 \%)$ \\
\hline Market & $0(0,00 \%)$ & $0(0,00 \%)$ & $6(85,71 \%)$ & $1(14,29 \%)$ & $7(9,46 \%)$ \\
\hline Hierarchy & $0(0,00 \%)$ & $1(25,00 \%)$ & $2(50,00 \%)$ & $1(25,00 \%)$ & $4(5,41 \%)$ \\
\hline \multicolumn{6}{|c|}{ Leadership in organization } \\
\hline Clan & $0(0,00 \%)$ & $21(38,89 \%)$ & $27(50,00 \%)$ & $6(11,11 \%)$ & $54(72,97 \%)$ \\
\hline Adherence & $1(12,50 \%)$ & $5(62,50 \%)$ & $2(25,00 \%)$ & $0(0,00 \%)$ & $8(10,81 \%)$ \\
\hline Market & $0(0,00 \%)$ & $0(0,00 \%)$ & $1(100,00 \%)$ & $0(0,00 \%)$ & $1(1,35 \%)$ \\
\hline Hierarchy & $0(0,00 \%)$ & $1(9,09 \%)$ & $8(72,73 \%)$ & $2(18,18 \%)$ & $11(14,86 \%)$ \\
\hline \multicolumn{6}{|c|}{ Human resource management } \\
\hline Clan & $1(1,54 \%)$ & $25(38,46 \%)$ & $32(49,23 \%)$ & $7(10,77 \%)$ & $65(87,84 \%)$ \\
\hline Adherence & $0(0,00 \%)$ & $2(100,00 \%)$ & $0(0,00 \%)$ & $0(0,00 \%)$ & $2(2,70 \%)$ \\
\hline Market & $0(0,00 \%)$ & $0(0,00 \%)$ & $3(100,00 \%)$ & $0(0,00 \%)$ & $3(4,05 \%)$ \\
\hline Hierarchy & $0(0,00 \%)$ & $0(0,00 \%)$ & $3(75,00 \%)$ & $1(25,00 \%)$ & $4(5,41 \%)$ \\
\hline \multicolumn{6}{|c|}{ Unity of organization } \\
\hline Clan & $0(0,00 \%)$ & $20(38,46 \%)$ & $25(48,08 \%)$ & $7(13,46 \%)$ & $52(70,27 \%)$ \\
\hline Adherence & $0(0,00 \%)$ & $6(60,00 \%)$ & $4(40,00 \%)$ & $0(0,00 \%)$ & $10(13,51 \%)$ \\
\hline Market & $0(0,00 \%)$ & $0(0,00 \%)$ & $3(100,00 \%)$ & $0(0,00 \%)$ & $3(4,05 \%)$ \\
\hline Hierarchy & $1(11,11 \%)$ & $1(11,11 \%)$ & $6(66,67 \%)$ & $1(11,11 \%)$ & $9(12,16 \%)$ \\
\hline \multicolumn{6}{|l|}{ Strategical focus } \\
\hline Clan & $0(0,00 \%)$ & $19(36,54 \%)$ & $26(50,00 \%)$ & $7(13,46 \%)$ & $52(70,27 \%)$ \\
\hline Adherence & $0(0,00 \%)$ & $7(63,64 \%)$ & $4(36,36 \%)$ & $0(0,00 \%)$ & 11 (14,86\%) \\
\hline Market & $0(0,00 \%)$ & $0(0,00 \%)$ & $4(100,00 \%)$ & $0(0,00 \%)$ & $4(5,41 \%)$ \\
\hline Hierarchy & 1 (14,29\%) & $1(14,29 \%)$ & $4(57,14 \%)$ & $1(14,29 \%)$ & $7(9,46 \%)$ \\
\hline \multicolumn{6}{|c|}{ Criteria for success } \\
\hline Clan & $0(0,00 \%)$ & $20(39,22 \%)$ & $25(49,02 \%)$ & $6(11,76 \%)$ & $51(68,92 \%)$ \\
\hline Adherence & $0(0,00 \%)$ & $4(44,44 \%)$ & $4(44,44 \%)$ & $1(11,11 \%)$ & $9(12,16 \%)$ \\
\hline Market & $0(0,00 \%)$ & $0(0,00 \%)$ & $2(100,00 \%)$ & $0(0,00 \%)$ & $2(2,70 \%)$ \\
\hline Hierarchy & $1(8,33 \%)$ & $3(25,00 \%)$ & $7(58,33 \%)$ & $1(8,33 \%)$ & $12(16,22 \%)$ \\
\hline
\end{tabular}

Source: Authors' work 
Hi-square test shows statistically significant difference between different groups of Dominant organization characteristic, $\chi 2(74,9)=15,225 ; p<0,05$. The post-hoc Turkey test shows significant difference only between groups of Market and Adherence from the perspective of the level of satisfaction of employees. The business result here is practically the only measure of success, and how to achieve it in a sharp competitive battle, in these organizations winning mentality, rationality and work responsibility is appreciated.

Also, statistically significant difference is shown between different groups of Leadership in organization, $\chi 2(74,9)=16,518 ; p<0,05$. The post-hoc Turkey test shows significant difference of group Adherence compared to groups Clan and Market, from the perspective of the level of satisfaction of employees. In organizations with clan culture, employees offer support one another and have strong interpersonal relations, meanwhile in an organization which dominates the competitive culture of the market they compete among themselves.

Also, statistically significant difference is shown between different groups of Strategical focus, $\chi 2(74,9)=18,625 ; p<0,01$. The post-hoc Turkey test shows significant difference of groups Market and Hierarchy compared to groups Clan and Adherence, from the perspective of the level of satisfaction of employees.

\section{Discussions and conclusions}

The empirical research of this work goes from a od assumption that the organizational culture is an organizational factor which affects the job satisfaction. During analysis it starts from the dominant type of organization culture, which the respondents estimate, and don't take into consideration other types of cultures which are present to a lesser extent in the organization according to the opinion of the respondents. Organizational culture is an important factor because it determines inner environment of the organization in which members of the organization do their job and receive desired results (Schein, 2004). Employee satisfaction connects to the type of organizational culture which his dominant inside the company, so different types of organizational culture connect to different degrees of employee satisfaction with the job they do.

Presented research is primarily focused on the analysis of the connections between organizational culture and degree of satisfaction, however for detailed analysis of factors which affect the degree of employee satisfaction it is mandatory to include other factors, from demographic, educational to other organization characteristics. Also, for future work the presented research may be extended to identification of instruments which can be used to increase the degree of satisfaction, as well as eventual models and cluster of employees.

\section{References}

1. Cameron, K. S., Quinn, R. E. (1999), Diagnosing and Changing Organizational Culture, Addison-Wesley, New York.

2. Denison, D. R. (1984), "Bringing Corporate Culture to the Bottom Line," Organizational Dynamics, Vol. 13, No. 2, pp. 5-22.

3. Handy, C. (1979), Gods of Management, Pan, London, UK.

4. Hutcheson, S. (1996), "The development of a measure of organizational climate", Unpublished Master Thesis, University of Witwatersrand, Johannesburg.

5. Janićijević N. (2013), Organizaciona kultura i menadžment, CID, Ekonomski fakultet, Beograd. 
6. Janićijević, N., Nikčević, G., Vasić, V., (2018), "The influence of organizational culture on job satisfaction", Economic Annals, Vol. 63, No. 219, pp. 83-114.

7. Johnson, J. J., McIntye, C. L. (1998), "Organizational Culture and Climate Correlates of Job Satisfaction", Psychological Reports, Vol. 82, No. 3, pp. 843-850.

8. Judge, T. A., Thoresen, C. J., Bono, J. E., Patton, G. K. (2001), "The Job Satisfaction - Job Performance Relationship: A Qualitative and Quantitative Review", Psychological Bulletin, Vol. 127, No. 3, pp. 376-407.

9. Kinicki, A. J., McKee-Ryan, F. M., Schriesheim, C. A., Carson, K. P. (2002), "Assessing Construct Validity of The Job Descriptive Index: Review and Meta-Analysis", Journal of Applied Psychology, Vol. 87, No. 1, pp. 14-32.

10. Lok, P., Crawford, J. (1999), "The Relationship Between Commitment and Organizational Culture, Subculture, Leadership Style and Job Satisfaction in Organizational Change and Development", Leadership \& Organizational Development, Vol. 20, No. 7, pp. 365-374.

11. Locke, E. A. (1969), "What is job satisfaction?", Organizational Behavior and Human Performance, Vol. 4, No. 4, pp. 309-336.

12. Lund, D. (2003), "Organizational Culture and Job Satisfaction", Journal of Business and Industrial Marketing, Vol. 18, No. 3, pp. 219-236.

13. Luthans, F. (2005), Organizational Behaviour, McGraw Hill Irwin, New York, NY.

14. Maclntosh, E. W., Doherty, A. (2010), "The Influence of Organizational Culture on Job Satisfaction and Intention to Leave", Sport Management Review, Vol. 13, No. 2, pp. 106-117.

15. Nystrom, P. C. (1993), "Organizational Cultures, Strategies and Commitments in Healthcare Organizations", Health Care Management Review, Vol. 18, No. 1, pp. 4349.

16. O'Reilly III, C. A., Chatman, J., Caldwell, D. F. (1991), "People and Organizational culture: a profile comparison approach to assessing person-organization fit", Academy of Management Journal, Vol. 34, No. 3, 487-516.

17. Odom, R. Y., Boxx, W. R., Dunn, M. G. (1990), "Organizational Cultures, Commitment, Satisfaction and Cohesion", Public Productivity and Management Review, Vol. 14, No. 2, pp. 157-169.

18. Robbins, S. P. (1993), Organizational behaviour, concepts, controversies and applications, 6th edition, Prentice-Hall, Englewood Cliffs, New Jersey.

19. Schein, E. H. (2004), Organizational Culture and Leadership, 2nd edition, Jossey Bass, San Francisco, CA.

20. Silverthorne, C. (2004), "The Impact of Organizational Culture and Person-Organization Fit on Organizational Commitment and Job Satisfaction in Taiwan", Leadership \& Organization Development Journal, Vol. 25, No. 7, pp. 592-599.

21. Sørensen, J. B., (2002), "The Strength of Corporate Culture and the Reliability of Firm Performance", Administrative Science Quarterly, Vol. 47, No. 1, pp. 70-91.

22. Wnuk, M. (2017), "Organizational Conditioning of Job Satisfaction", A Model of Job Satisfaction, Contemporary Economics, Vol. 11, No. 1, pp. 31-44. 


\section{About the authors}

Olivera Simovic is a teaching assistant at the Faculty of Tourism and Hospitality Management in Kotor. She holds a master's degree in tourism science at the Faculty of Tourism and Hospitality Management. Currently a Phd student at the Faculty of Economy in Belgrade. She participated in Erasmus + CULTURWB projects. Research interests are in the area of organisational culture and management, and leadership in organisational changes. Olivera Simovic published several scientific papers in international and national journals and participated in many scientific international conferences. The author can be contacted at oliveras@ac.me.

Djurdjica Perovic Ph.D. is an Assistant Professor at the Faculty of Tourism and Hospitality Management in Kotor. She received PhD at Faculty of Mathematical Sciences, University of Novi Sad, with dissertation thesis: "Current Situation and Development Directions of Montenegrin Seaside in the function of successful market appearance". She participated in Projects - Heric, IPA, Erasmust. Her main research interests are Tourism, Tourist Regions, Cultural Tourism, Selective forms of tourism. She has published more than 30 research papers and participated at more than 20 scientific conferences. She is the author and co-author of two monographs. The author can be contacted at duda@ac.me.

Milica Raicevic is a teaching assistant on subjects in the area of marketing and management at the Faculty of economy and business, University Mediterranean in Podgorica. She holds a master's degree obtained at the Faculty of economy. University of Belgrade. Currently she is on the 3rd year of studies for obtaining a PhD at the Faculty of economy and business, University Mediterranean in Podgorica. Areas of interest and research include: marketing, services marketing, strategic management. Milica Raicevic published several scientific papers in international and national journals and participated in many scientific international conferences. The author can be contacted at milica.raicevic@unimediteran.net. 